\title{
Transition to university: the role played by emotion
}

\author{
W. McMillan
}

\begin{abstract}
Students experience transition to university as challenging. Recent studies implicate emotion in university success. This paper reports on a pilot study to examine the extent to which school to university transition is experienced as emotional. Understanding the role of emotion in this transition can inform mechanisms for student support. This qualitative study used focus group interviews to elicit insider accounts of transition. The pilot cohort consisted of a tutorial group of twenty-eight students from within the class of one hundred and eight first year students at one Faculty of Dentistry in South Africa. Three focus group interviews were conducted. Issues identified in the literature as significant were used to analyse the data. Eleven descriptive tags related to transition and associated with emotion were identified from the data. These were clustered into four themes - 'academic challenges', 'friends and family', 'outside constraints' and 'identity'. Findings suggest that emotions are a natural part of the experience of transition. Drawing on insights of students' emotional needs, it is suggested that students in transition need a roadmap and a guide. A framework, to be used as a roadmap, is suggested. Peer mentoring is discussed as a mechanism for mediating the framework and thus for supporting students in the transition.
\end{abstract}

Keywords: undergraduate students; school to university transition; emotions; professional identity development; peer mentoring

\section{Background}

The transition from school to university is experienced by most university students as challenging (1-4). Challenges include an increase in workload and academic standard (5), loneliness (6) and homesickness (7). Transition difficulties lead frequently to academic under-performance and to withdrawal from university $(8,9)$. Suggestions have been made to support retention and throughput by improving institutional culture (10), through initiatives to improve the quality of teaching (11), and by suggesting ways to support student learning $(12,13)$. Swail et al. (14) provide an explanation of transition that highlights cognitive, institutional and social factors. They (14) suggest a comprehensive strategy for improving student retention, including academic and student services, curriculum and teaching, and financial aid.

However, more recently, social theory has highlighted that transitions are not just about knowledge transfer but concern a restructuring of what the person does and who the person perceives him or herself to be (15). This body of literature draws attention to the 
complexity of learning, and highlight its emotional nature (16-21). Some learning experiences are positive and provoke emotions of anticipation, exhilaration and discovery (22), while others are disturbing and evoke feelings of vulnerability and insecurity (17). Learning is not limited to the realm of individual cognition (17). The entire individual is part of the learning process (17). Learning in not just the acquisition of memories, habits and skills, but also about the formation of an identity as 'university student' $(15,23,24)$. It involves becoming an 'insider' into new ways of doing things (25). Learning at university is thus a 'profoundly reflexive and emotional construct' because it involves the undoing of earlier learning in the context of a new environment with different subjects, learning approaches and teaching styles (17, p. 597). The new learning context, and transition into it, is integral to successful learning, and emotion is implicated in this process. Christie et al. (17) highlight the important role that confidence, motivation, perseverance, and creativity play in transition to, and success at, university. Students' engagement with the new learning environment is tentative, and affected by a variety of psychological issues $(21,26)$. Transition to university is experienced as a 'culture shock' - brought on by the anxiety of not knowing what is expected (22, p. 1). This anxiety directly impacts on the learning process $(22,27)$. Learning is thus experienced as risky and inherently uncertain $(21,26)$. The challenge for a student on entering university is therefore to come to know the reality of the new learning environment (17). Understanding the extent to which emotion is implicated in transition to university has the potential to inform student support that goes beyond traditional interventions of academic development and curriculum innovation.

This paper reports on a qualitative pilot study that examined whether first year dentistry and oral hygiene students at a Faculty of Dentistry in South Africa experienced the transition as emotional, and if they did, the nature of these emotions. Explicating the extent and nature of emotion in school to university transition has the potential to inform student support mechanisms. While current mechanisms privilege academic support and development (14), evidence of the emotional nature of school to university transition might inform university interventions that target the socio-emotional components of learning.

\section{Methodology}

A pilot study design was selected because this design has the potential to explicate the concept (28) of emotional transition, to uncover errors in current assumptions about this concept (28), and to inform designs for further confirmatory studies (29) of the emotional nature of school to university transition. Conn (30) argues that methodologically sound pilot studies have a contribution to make to knowledge in a domain, guiding the thinking of other investigators both within the specific research area and the discipline as a whole. A qualitative approach was used to elicit the insider accounts of transition to university required for the study (31). Qualitative research has 
the potential to provide complex descriptions of how people experience a given social reality - in this case, the transition to university $(32,33)$. Qualitative research provides insight into the experiences, beliefs and emotions of those whose experience is being researched (34).

The pilot cohort was purposively selected from within the class of one hundred and eight first year dentistry and oral hygiene students. At the study institution, all first year students are randomly allocated to one of four smaller classes for their core integrated module, 'Academic Literacy'. This module focuses on the competencies pre-requisite for survival at university, and had components of academic writing, digital and information literacy, and life skills (such as time management, substance abuse, and examination strategies). One of these classes, comprising twenty-eight students, was selected for the pilot. The researcher is the teacher of this particular class. The cohort is representative of the first year student body because of the random allocation of the students to the smaller classes.

Ethics approval was obtained from the university's Research Ethics Committee. Students were asked to participate in focus group discussions, and to organize themselves into these groups. Written consent to participate in the focus groups was obtained from each student beforehand. This form indicated how the researcher would ensure confidentiality, and also required that the student participant sign assurance that s/he would not disseminate other people's opinions outside of the interview context. Focus group interviews are intended to generate information on collective experiences, views, and beliefs and the meanings that are attributed to them $(35,36)$. Instead of the researcher posing questions to individuals, participants are encouraged to talk to one another (37).

Fifteen of the twenty eight students in the selected class consented to participate in the study. The demographics of this study cohort are represented in Figure 1. All the students in the cohort were South African nationals.

Fig 1. Student cohort demographics

\begin{tabular}{|l|l|l|l|l|l|l|l|l|}
\hline $\begin{array}{l}\text { Stude } \\
\text { nt }\end{array}$ & $\begin{array}{l}\text { Program } \\
\text { me }\end{array}$ & Age & $\begin{array}{l}\text { Prior } \\
\text { employme } \\
\text { nt }\end{array}$ & Sex & $\begin{array}{l}\text { Ethnic } \\
\text { ity }\end{array}$ & $\begin{array}{l}\text { Social } \\
\text { class }\end{array}$ & $\begin{array}{l}\text { Urba } \\
\text { n/ } \\
\text { rural }\end{array}$ & $\begin{array}{l}\text { Home } \\
\text { langua } \\
\text { ge }\end{array}$ \\
\hline 1 & dentistry & 19 & "gap" year & male & white & middle & $\begin{array}{l}\text { small } \\
\text { town }\end{array}$ & $\begin{array}{l}\text { Afrikaa } \\
\text { ns }\end{array}$ \\
\hline 2 & dentistry & 18 & school & female & white & middle & $\begin{array}{l}\text { small } \\
\text { town }\end{array}$ & $\begin{array}{l}\text { Afrikaa } \\
\text { ns }\end{array}$ \\
\hline 3 & dentistry & 18 & school & female & white & middle & small & Afrikaa \\
\hline
\end{tabular}




\begin{tabular}{|c|c|c|c|c|c|c|c|c|}
\hline & & & & & & & town & ns \\
\hline 4 & dentistry & 18 & school & female & white & middle & urban & $\begin{array}{l}\text { Afrikaa } \\
\mathrm{ns}\end{array}$ \\
\hline 5 & $\begin{array}{l}\text { oral } \\
\text { hygiene }\end{array}$ & 18 & school & female & African & working & rural & Xhosa \\
\hline 6 & $\begin{array}{l}\text { oral } \\
\text { hygiene }\end{array}$ & 34 & $\begin{array}{l}\text { unskilled } \\
\text { worker }\end{array}$ & male & African & working & rural & Xhosa \\
\hline 7 & $\begin{array}{l}\text { oral } \\
\text { hygiene }\end{array}$ & 25 & waitron & female & African & working & rural & Xhosa \\
\hline 8 & $\begin{array}{l}\text { oral } \\
\text { hygiene }\end{array}$ & 20 & $\begin{array}{l}\text { dental } \\
\text { assistant }\end{array}$ & female & African & working & urban & Xhosa \\
\hline 9 & dentistry & 18 & school & male & Indian & middle & urban & English \\
\hline 10 & dentistry & 18 & school & male & Indian & middle & urban & English \\
\hline 11 & dentistry & 18 & school & female & Indian & middle & urban & English \\
\hline 12 & dentistry & 19 & $\begin{array}{l}\text { started } \\
\text { university } \\
\text { and left } \\
\text { (cost) }\end{array}$ & female & $\begin{array}{l}\text { "mixed } \\
\text { race" }\end{array}$ & working & urban & $\begin{array}{l}\text { Afrikaa } \\
\text { ns }\end{array}$ \\
\hline 13 & dentistry & 18 & school & male & $\begin{array}{l}\text { "mixed } \\
\text { race" }\end{array}$ & working & urban & English \\
\hline 14 & dentistry & 18 & school & female & $\begin{array}{l}\text { "mixed } \\
\text { race" }\end{array}$ & middle & urban & English \\
\hline 15 & dentistry & 19 & $\begin{array}{l}\text { started } \\
\text { university } \\
\text { and left } \\
\text { (cost) }\end{array}$ & male & African & working & rural & Sotho \\
\hline
\end{tabular}

Three focus groups were formed, with seven students in one group and two further groups of four students each. An interview of about 90 minutes was conducted with each group. These interviews took place during the third month of the students' first academic year. The semi-structured interview protocol consisted of two questions 'What was it like coming to university' and 'What does being a dentist/oral hygienist mean to you'. Each interview was audio-recorded and transcribed by the researcher.

The interview transcripts were initially analysed using 'grounded theory' (48). This approach relies on a line by line analysis of the transcripts where emerging topics are identified and coded (49). Where topics were common for more than one student, a "descriptive tag" was tentatively identified (49). Thereafter a grid was drawn up which recorded both the quotations identified for each topic, and the relationship between the diverse and various topics and the limited descriptive tags which encompassed the topics. At this stage, 11 descriptive tags related to transition and associated with emotion 
were identified from the data (see Fig 2). These descriptive tags were then mapped against the issues identified in the literature as significant to transition - 'academic challenges', 'friends and family', 'outside constraints' and 'identity'. Figure 2 indicates the relationship between the tags and the themes.

Figure 2 Relationship between tags and themes

\begin{tabular}{|l|l|l|l|}
\hline $\begin{array}{l}\text { Academic } \\
\text { challenges }\end{array}$ & $\begin{array}{l}\text { Friends and } \\
\text { family }\end{array}$ & $\begin{array}{l}\text { Outside } \\
\text { constraints }\end{array}$ & Identity \\
\hline $\begin{array}{l}\text { knowing what to } \\
\text { expect }\end{array}$ & family support & $\begin{array}{l}\text { home } \\
\text { responsibilities }\end{array}$ & language \\
\hline feeling familiar & making friends & finances & $\begin{array}{l}\text { becoming a dentist/ } \\
\text { oral hygienist }\end{array}$ \\
\hline $\begin{array}{l}\text { knowing what is } \\
\text { going on }\end{array}$ & anonymity & \\
\hline $\begin{array}{l}\text { relationship with } \\
\text { lecturers }\end{array}$ & & & \\
\hline
\end{tabular}

Using literature as an interpretive lens helps the researcher recognize and interpret patterns beyond the surface level of the data (38), and ensures that explanations generated from the study build upon what is already known about the study topic (38). The themes in the literature $(1-7,10,14,16,17,19,20,23,27)$ and the descriptive tags were then mapped against each other (see Fig 2). This strategy resulted in a graphic representation of the way in which the emotional responses of the students in the cohort were associated with the already acknowledged and researched challenges identified in the transition to university literature. The validity and reliability of the researcher's interpretations and conclusions were checked through a process of triangulation (50). All fifteen students were individually interviewed in their second academic year, and the transcript of their focus group interview as well as the researcher's interpretation of what they had said in the focus group interview was the focus of the one-on-one interview. In this way the researcher checked her interpretation of the emotional import of what each student had said in his or her first academic year.

\section{Results and discussion}

In the discussion that follows, the way in which students associated emotion with transition will be explicated using quotations from the focus group interviews. The emotional component of each quotation is italicized.

\section{Academic challenges}

Given that the transition from school to university relates specifically to academic environment, it was inevitable that students should discuss this aspect of the transition 
in the interviews (23). Four descriptive tags emerged related to the academic environment - 'knowing what to expect', 'feeling familiar', 'knowing what is going on', and 'relationship with lecturers'. Much of what students said about the academic transition drew on their experience of the shift from small intimate classrooms with familiar teachers at school to the university context of whole class lecturing by numerous, and sometimes unfamiliar, lecturers. Except for the "Academic Literacy" module discussed earlier in this paper, all other courses were taught to the whole class that is 81 dentistry students and 27 oral hygiene students.

\section{Knowing what to expect}

'Knowing what to expect' was raised as significant and elicited strong emotional responses. Students expressed fear with regard to academic expectations which were, for them, clearly unknown and consequently not clear, 'It was exciting but at the same time scary because you didn't know what to expect'; 'I was very frightened in the beginning because everyone says that university is so difficult'. The combined sense of 'newness' and lack of clarity regarding what to expect was experienced as threatening, 'when I first went to university I felt very threatened'; 'I was really frightened that I wouldn't get it right'.

\section{Feeling familiar}

Stress in the academic environment was further exacerbated by an unfamiliar physical environment. Before students could even engage with the academic challenges of the classroom, they had to find their way to the classroom, a further experience provoking emotion, 'It is difficult. I tried to find the class for two weeks. If you ask someone, they say B-what-what. My god, I don't even know that place'. Some students implied that they felt familiar with neither the academic nor the physical environment, 'My first day was a bit confused. When I arrived in the class, it was a whole new world. It might be difficult sometimes'.

\section{Knowing what is going on}

'Knowing what is going on' appeared to be at the heart of survival in the period of transition. However, once students knew what was going on, they realised that the academic challenges were very different from school and consequently stressful, 'Everything is seriously really, really difficult'. Larger workload was noted by almost all of the students and associated with stress, 'The workload is much more so some of us find it hard to actually cope'. This stress was ameliorated for those who had some prior knowledge of the discipline, as did this student who had worked previously as a dental assistant, 'My first day was nice because I know when she talks about periodontitis, at least I have some background. I know what is going on'. 


\section{Relationship with lecturers}

Some academic challenges related specifically to the support from lecturers (23). Students noted the different relationship with school teachers and university lecturers. Relationships with teachers were 'more personal' and with lecturers were 'more formal'. These differences resulted in initial feelings of fear with regard to lecturers, 'The lecturer - I was very afraid in the beginning'. Some students reported that they 'keep quiet' because they 'feel shy' to ask questions in class. Others indicated that support from lecturers helped them learn and this assistance had an emotional component, 'They are nice. They see you are struggling. (They say) come to me and I will personally help'. Perceived lack of support was, however, associated by students with potential failure, 'He doesn't care and is out to fail you'.

Evidence indicates students' sense of disorientation and emotional vulnerability in the transition from school to university. Their accounts hint at potential threats to successful academic performance and suggest that students did not knowg what the academic expectations were. Thus, they were missing classes because the venue locations were unclear, and struggling with the workload. However, the role of supportive lecturers in this period is also signalled. These lecturers helped students understand what the expectations were and assisted them to bridge conceptual gaps.

\section{Influences}

Social factors affect students' ability to cope with the transition to university (23). The significance of emotional support, already hinted at in the testimony regarding lecturers, was very evident for the students in this study.

\section{Family support}

Family support provided a continuity with the 'old life' (39). It provided opportunities for those from the familiar world of 'home' to support and enlighten. Students with family members who had been to university were able to draw on insight from these people. Their support was experienced as comforting, as one student described, 'sitting me down and telling me, 'You are going to university to study, to get your degree. Don't spend your time loafing around ... sit down and study. ... (M)y father is putting pressure on me ... I like the fact that he's doing that'.

For others, 'family' support was simply knowing that someone cared about your studies, 'I have a family close by here who are like a second family to me - they sms me before I am writing a test. They do a lot for me. I am not sure what I would have done without them.' For first generation university students, whose family members could not provide the insider experience support, family support was expressed as having people who 'believed' in you, particularly at the times when it was most difficult, 'They keep on 
calling me. They didn't go to 'varsity but (they) are encouraging me to do the best so that from me comes the best. Many times it is tough'.

\section{Making friends}

The preceding testimony indicates how the love and care of family were closely associated with coping during the period of transition. Students living in residence associated the friendships that they forged at university as similar to family relationships, 'like forming our own families. I didn't know him, and now he is like my brother'. While not explicit, it is arguable that an emotional sense of belonging is implicit in this comparison to family.

Friendship was also argued by the students as a significant contributor to emotional support, 'I think if it hadn't been for my friends, things might have been very different difficult. They help you to focus on what is important'. Implicit in this quotation is a relationship between the emotional support of friends and academic success. This relationship was evident in comments from other students as well, 'I was lucky. My whole friendship circle is like that. If we have to study - we were not happy - but we have to and we do'. Friendship also provided students with information that assisted their transition to university because it helped them to become familiar with the university, 'It was easy for me because one of my friends from school was in the same course as me at university. I could ask him - where is this building? So, it wasn't so awful'.

Friendship was, however, also fraught with emotional stress in the period of transition. Similar to coming to university, 'making new friends' was associated with not knowing what to expect and feeling unfamiliar. 'Making friends' was a theme spontaneously raised in all three focus group interviews, and all the students concurred that arriving at university not knowing anyone else was an extremely emotionally challenging activity, 'You don't know anybody. I was just afraid, I was the only one from my matric class that was studying dentistry'; 'I was nervous - like - to some people you don't know. I didn't know even one person in the class'. Student testimony suggested that they were faced, simultaneously, with the desire to belong and to have friends, and with a fear of getting involved with the 'wrong' group of students or being befriended for the 'wrong' reasons, 'When you are far from home you are not sure whether people will be good friends together, so you are not sure whether you are going to make friends with me or not. You don't want to get involved with drugs'; 'You are making friends for you, but you are not sure if they are making friends for who you are. You don't know if they accept you. So you are worried about making friends with people'; 'It comes down to trust though you have to trust that the person won't do that. It is scary - you have to trust'. 
Testimony has indicated that family and friendship played a significant role in the extent to which students felt supported in the period of transition. The possibility of a sense of alienation impacting negatively on learning is signaled in the literature $(40,41$, 4).

\section{Anonymity}

A number of students associated the sense of being alone in the initial phase of transition with feelings of anonymity. The sense of anonymity was pervasive. It was associated with being a student ('The class was huge. I used to sit in the middle at the back and like, I'm a nobody, I'm a nothing'), with making friends ('There is also the emotional stress. You are used to being at school where people know you. You are here and no-one knows you and you are making friends for you'), and with communicating with lecturers ('At school, you actually had a relationship with the teacher. Here, you walk past the lecturer and he doesn't know you'). While emotional words were not always associated specifically with experiences of anonymity, it is arguable that feeling anonymous in itself is a significant emotional experience.

\section{Outside constraints}

Mackie (9) highlights the important role that 'external forces' play in the way in which issues outside the university affect students' experiences of university. Two such constraints, associated with emotion - home responsibilities and finances - were raised in the focus group interviews.

\section{Home responsibilities}

Only one student cited part-time employment, common in the literature $(20,43,44)$, as a constraint, 'It is sometimes difficult for me because weekends, I have to go to work the whole night'. None mentioned child-care $(20,43,44)$, but one student indicated how care for a sick parent made similar demands. She explained that being available for her mother was a priority, and described how being able to go home when she didn't have academic commitments made a significant contribution to how she felt about being at university, 'My mother is really ill so that is a huge factor in my life. So that makes me feel much better because when I am done here, I can go home immediately. I feel much more secure now that I can go home'.

Students weighed up whether it was easier to focus on academic work while living at home or living in residence. Their responses suggested that both contexts provided challenges. Students living at home highlighted obligations felt towards family members and the impact of these on study time, 'It isn't always easy. You get the family coming to you and you can't say 'Go away, I don't want you here, I'm busy'. I have to consider other people when you are at home and studying yourself'. Students living in residence, while 'free' of family obligations, indicated that new household responsibilities made 
finding time for academic work challenging, 'Now I must do everything! Find time to study. Also time to clean and dust. It was a huge adjustment for me'.

\section{Finances}

Finance is acknowledged as a significant constraint on students' experiences at university $(20,45,46)$. At the most fundamental level, poorer students in the study experienced stress related to living costs, 'What was difficult for me was having to travel each day. I take two taxis - I live far. It's not bad if you live near the university but travelling on the two taxis costs a lot of money. So that's a bit hard for me - like, my finances and stuff. However, even those students who came from families with adequate finances felt that lack of experience made managing a budget stressful. Running out of money was an ever present threat, 'And then there is the thing of having to take care of the money that you get. Making sure that you don't run out. The first two months I just spent everything because I wasn't used to that - there are a lot of challenges'; 'There is a lot of stress like money shortages. The scary thing was the money issue. I was always afraid of running out of money'.

\section{Identity}

Identity emerges in the literature as a significant theme in students' experience of transition to university $(16,17,23)$. In the focus group interviews, identity emerged as an emotional context for the students. This identity was expressed in terms of home language and in terms of the professional they wanted to become.

\section{Language}

Language played a significant role in students' perceptions of transition at this Englishmedium university. For students who did not have the language of instruction as a home language and who had not been schooled in the language of instruction, language was associated with feelings of exclusion at the point of transition, 'English was a huge adjustment'; 'I stressed about the English'; 'You think, oh my gosh, I have to talk English now'. For these students, language competence was associated with academic success, 'In chemistry, he said 'potassium'. And then I realized he meant 'kaliem'. There is that fear - you must overcome that fear for that other language'; 'It was a huge adjustment - learning in English. It was terrible in Life Sciences You know everything in Afrikaans and now you must know it in English as well'.

There were also, for these students, social challenges in not being completely competent in the social language of other students. Firstly, these students were concerned with 'fitting in' and being socially accepted, 'I was afraid. I thought that there would be few of us - that they would all be English, and that I would need to fit in'. Secondly, their language competence sometimes excluded them from social engagement with other students, 'Sometimes, students, they sit and speak, so you can't interact with them. It is 
quite difficult'. Competence in the language of instruction and socialization was obviously not an issue for all students. However, the foregoing testimony indicates the potential that language difference has to construct 'insiders' and 'outsiders' in ways that might lead to student alienation.

\section{Becoming a dentist/oral hygienist}

Mackie (9) reminds of the significance of commitment to student retention, and highlights the relationship between commitment and long term goals. Students signaled strongly that their desire to become a dentist/oral hygienist helped provide a focus during the difficult time of transition (47). Emotive terms were associated with this commitment. Firstly, there was strong evidence that students associated privilege with being selected to study dentistry/oral hygiene, 'You're fortunate enough to be going to university. You have to appreciate it'; 'I was very happy. It is a privilege for me to come to university'. There was, further, an associated sense of beginning a journey for which they had actively planned (47). This sense of choice was expressed in comments such as, 'I am very passionate about wanting to serve others. Being a dentist you are going to serve people'. Finally, student expressed joy and excitement as they tried on this desired identity (47), 'You feel like you can't wait until you get into your white coat. You feel so professional'. These comments suggest that taking on the professional identity of a dentist/oral hygienist played a significant role in helping students to feel like 'insiders', even during the difficult period of transition.

\section{Conclusion}

This study drew on the experiences of a pilot cohort of first year oral hygiene and dentistry students to examine whether these students had experienced the transition from school to university as emotional. Where emotions were present, the study attempted to explicate the nature of these emotions. Analysis of the focus group data identified four areas in which these students specifically experienced emotion. While it cannot be argued that this small cohort is representative of all first years students, the students of the tutorial group that was selected for the pilot had been randomly allocated from the entire first year cohort. It is thus arguable that the issues raised by these students will resonate for other first year students in similar contexts. Certainly the literature from other countries where students enter directly into professional programmes (51) suggests that the challenges experienced by this South African cohort are not unique. There is also a growing interest internationally to support students who are the first in their family to attend university with what is clearly a challenging transition $(16,17,19,20,23)$. Widening access globally (20) has meant that the number of first generation students attending university is growing $(16,17,19,20,23)$. However, current evidence suggests that these students are less likely to be academically successful than students from homes where parents and siblings have already been to university $(8,9,14,19)$. There is clearly a need for research into how they experience the 
transition and what mechanisms might be put in place to facilitate this emotional transition. Further multi-site large scale studies will provide insight into the transferability of these findings.

Findings from the pilot corroborate the emerging literature (16 - 21) and give some specification to the emotional nature of school to university transition. Students' greatest emotional fear appeared to be that of alienation - being an outsider without friends (23). Their most positive emotion was focused on the development of a professional identity (47). Heathcote and Taylor (52) outline a framework that draws on institutional change theory (53). This framework has the potential to suggest a model for student emotional support during the transition that builds on these two emotional needs. Heathcote and Taylor (52) suggest that, in transition, students move through a number of stages, although not necessarily sequentially. Adapted for emotional support, these stages might be expressed as:

- establishing a sense of urgency (awareness of the need to adopt new identities as student and dentist/oral hygienist)

- forming a powerful guiding coalition (identifying support for the transition peers, teachers, support services, academic skills)

- creating a vision (forming an image of the future identities as student and dentist/oral hygienist)

- communicating the vision (understanding that there is a way of 'being' a student of dentistry/oral hygiene and later a dentist/oral hygienist, recognizing these identities, making sense of them and how they are manifest)

- acting on the vision (taking steps to act out the new identity, including the use of appropriate language and dress)

- planning for and creating short-term wins (identifying the 'steps' along the way to becoming a successful dentist/oral hygienist, and recognizing how learning opportunities at university constitute these 'steps')

- consolidating improvements and producing still more change (using available feedback, including formative and summative assessment, to measure attainment towards becoming the successful university student and future dentist/oral hygienist)

- owning the new identity (recognizing successful steps towards the desired identity as university student and dentist/oral hygienist, and celebrating achievements in this regard).

Dental/oral hygiene curricula are designed to provide students with opportunities for developing the desired competencies. However, the student needs to make the connection that each small activity in which s/he engages, however apparently irrelevant, is directed towards the desired goal of being a student (23) and a dentist/oral 
hygienist (47). Preliminary findings suggest that, on registration, students have little understanding of how different it is to be a university student. They also do not understand exactly what it means (besides wearing a white coat and caring about people) to be a dentist/oral hygienist. What students need in the transition is a roadmap and a guide.

The stages, adapted from Heathcote and Taylor (52), suggest the roadmap. To be successful, students need to journey through those stages. However, they need to be accompanied on that journey by someone who has travelled that path already. This experienced traveler can help them identify where they are on the journey. S/he can help them anticipate and prepare for the learning that can be made from each part of the journey. And this mentor can help them to identify parts of the journey that they still need to make and how to prepare themselves for those aspects. The study findings suggest that not all students feel comfortable to approach a teacher (or even know that they should). They therefore need to be provided with the human resource - the peer who has travelled this path recently. Peer mentoring has the potential to fulfill such a function. Mentoring is the 'one-to-one, non-judgmental relationship in which an individual mentor voluntarily gives time to support and encourage another' (54). Peer mentoring allows new university students to be prepared for, and taken through, the transition to university $(55,56,57)$. Training of peer mentors in the stages identified by Heathcote and Taylor (52) has the potential to create a support programme that is targeted both at students' needs, and of their greatest emotional challenges and desires, in this period of transition. The peer mentoring programme thus has the potential to provide an unconditional friend who will help the novice become what they desire - a successful student and dentist/oral hygienist.

\section{ACKNOWLEDGMENTS}

I would like to thank all the students who took part in this research and who so willingly sacrificed their time and honestly shared their experiences of transition to university. 


\section{References}

1. Morosanu L, Handley K, O'Donovan B. Seeking support: researching first-year students' experiences of coping with academic life. High Educ Res Dev 2010: 29: 665-678.

2. Palmer M, O'Kane P, Owens M. Betwixt spaces: student accounts of turning point experiences in the first-year transition. Stud High Educ2009: 34: 37-54.

3. Clark M. Negotiating the freshman year: Challenges and strategies among first year college students. J Coll Stud Dev 2005: 46: 296-316.

4. Smith K. An investigation into the experience of first-year students of English at British universities. Arts \& Hum High Educ 2004: 3: 81-93.

5. Lowe H, Cook A. 2003. Mind the gap: Are students prepared for higher education? J Furt Higher Educ 2003: 27: 53-76.

6. Pargetter R. Transition: from a school perspective. J Inst Res 2000: 9: 14-21.

7. Burt CDB. Concentration and academic ability following transition to university. An investigation of the effects of homesickness. J Environ Psychol 1993: 12: 333-342.

8. Christie H, Munro M, Fisher T. Leaving university early: exploring the differences between continuing and non-continuing students. Stud High Educ 2004: 29: 617-636.

9. Mackie SE. Jumping the hurdles - undergraduate student withdrawal behavior. Innov Educ Teach Int 2001: 38: 265-276.

10. Tinto V, Pusser B. Moving from theory to action: Building a model of institutional action for student success. Paper prepared for the National Post-Secondary Education Corporation, 2006.

11. Biggs J. Teaching for quality learning at university. What the student does. Berkshire, UK: SRHE \& Open University Press, 2003.

12. Foster D, Russell DR. Writing and learning in cross-national perspective. Transitions from secondary to higher education. New Jersey: Lawrence Erlbaum, 2002.

13. Angelil-Carter S. (ed.) Access to success: Literacy in academic contexts. Cape Town: UCT Press, 1998.

14. Swail WS, Redd LW, Perna LW. Retaining minority students in higher education. A framework for success. ASHE-ERIC Higher Education report 30. New Jersey: Wiley Periodicals, 2003.

15. Crafter S, Maunder R. Understanding transitions using a sociocultural framework. Educ Child Psych 2012: 29: 10-18.

16. Christie H. Emotional journeys: young people and transitions to university. Brit J Sociol Educ 2009: 30: 123-136.

17. Christie H, Tett L, Cree VE, Hounsell J, McCune V. 'A rollercoaster of confidence and emotions: learning to be a university student. Stud High Educ 2008: 33: 567-581.

18. Burke PJ. Men accessing education: Masculinities, identification and widening participation. Brit J Sociol Educ 2007: 28: 411-424.

19. Archer LM, Hutchings M, Ross A. Higher education and social class. London: RoutledgeFalmer, 2003. 
20.Leathwood C, O'Connell P. 'It's a struggle': the construction of the 'new student' in higher education. J Educ Policy 2003: 18: 597-615.

21. Gallacher J, Crossan B, Field J, Merill B. Learning careers and the social space; Exploring the fragile identities of adult returners in the new further education. Int $J$ Lifelong Educ 2002: 21: 493-509.

22. Griffiths S, Winstanley D, Gabriel Y. Learning shock: The trauma of return to formal learning. Manage Learn 2005: 36: 275-297.

23. Scalon L, Rowling L, Weber Z. 'You don't have like an identity ... you are just lost in a crowd': Forming a student identity in the first-year transition to university. J Youth Stud 2007: 10: 223-241.

24. Wenger E. Communities of practice: Learning, meaning and identity. Cambridge: Cambridge University Press, 1998.

25. Lave J, Wenger E. Situated learning: Legitimate peripheral practice. Cambridge: Cambridge University Press, 1991.

26. Jackson C. Transitions into higher education: Gendered implications for academic selfconcept. Oxford Rev Educ 2003: 29: 331-346.

27. Lucey H, Reay D. Carrying the beacon of excellence: Social class differentiation and anxiety at a time of transition. J Educ Policy 2002: 17: 321-336.

28. Lanphear JH. Commentary: Pilot studies. Educ Health 2001: 14: 33-35.

29. Arain M, Campbell MJ, Cooper CL, Lancaster A. What is a pilot or feasibility study? A review of current practice and editorial policy. BMC Med Res Methodol 2010: 10: 67. Available http://www.biomedcentral.com/1471-2288/10/67 Accessed 2 July 2012.

30. Conn VS. Rehearsing for the show: The role of pilot study reports for developing nursing science. West J Nurs Res 2010: 32: 991-993.

31. Edmunds S, Brown G. Doing qualitative research in dentistry and dental education. Eur J Dent Educ 2012:16: 110-116.

32. Bower E, Scambler S. The contributions of qualitative research towards dental public health practice. Comm Dent Oral Epidemol 2007: 35: 161-169.

33. Willms DG, Best JA, Taylor DW, Gilbert JR, Wilson DMC, Lindsay EA, Singer J. A systematic approach for using qualitative methods in primary prevention research. Med Anthropol 1990: 4: 391-409.

34. McMillan W. Finding a method to analyze qualitative data: Using a study of conceptual learning. J Dental Educ 2009: 73: 53-64.

35. Gill P, Stewart K, Treasure E, Chadwick B. Methods of data collection in qualitative research: Interviews and focus groups. Br Dent J 2008: 204:291-295.

36. Morgan DL. The focus group book. London: Sage, 1998.

37. Kitzinger J. Introducing focus groups. Br Med J 1995: 311:299-302.

38. McMillan JH, Schumacher S. Research in education: A conceptual Introduction. New York: Longman, 2001.

39. Chow K, Healey M. Place attachment and place identity: First-year undergraduates making the transition from home to university. J Environ Psychol 2008: 28: 362-372. 
40.Case J. Alienation and engagement: development of an alternative theoretical framework for understanding student learning. High Educ 2007a: 39: 321-332.

41. Case J. Alienation and engagement: exploring students' experiences of studying engineering. Teach High Educ 2007b: 12: 119-133.

42. Mann SJ. Alternative perspectives on the student experience: alienation and engagement. Stud High Educ 2001: 26: 7-19.

43. Manthei RJ, Gilmore A. The effect of paid employment on university students' lives. Educ \& Train, 2005: 47: $202-215$.

44. Long M, Hayden M. Paying their way: a survey of Australian undergraduate university student finances, 2000. Canberra: Australian Vice-Chancellors' Committee, 2001.

45. Moreau M, Leathwood C. Balancing paid work and studies: working (-class) students in higher education. Stud High Educ 2006: 31: 23-42.

46. Paulsen MB, St John EP. Social class and college costs. Examining the financial nexus between college choice and persistence. J High Educ 2002: 73: 189-236.

47. Weidman J. Undergraduate socialization: A conceptual approach. In: Smart J, editor. Higher education: Handbook of theory and research. New York: Agathon, 1989.

48. Strauss A. Qualitative analysis for social scientists. Cambridge, UK: Cambridge University Press, 1987.

49. McMillan WJ. Finding a method to analyze qualitative data: Using a study of conceptual learning. J Dent Educ 2009: 73:53-64.

50. Cohen L, Manion L. Research methods in education. London: Routledge, 1994.

51. Niemi PM, Vainiomaki PT. Medical students' distress - quality, continuity and gender differences during a six-year medical programme. Med Teach 2006: 28: 136-141.

52. Heathcote E, Taylor PG. The potential contribution of change management literature to understand and support student transition. Proceedings HERDSA 2007 Enhancing Higher Education. Theory and Scholarship. Adelaide, South Australia, 2007. Available at http://eprints.qut.edu.au/10082/1/10082.pdf (accessed 3 June 2011).

53. Kotter JP. Leading Change: Why transformation efforts fail. Har Bus Rev 1995: 85(1). Available

https://secureweb.mcgill.ca/hr/sites/mcgill.ca.hr/files/leading change john kotter.p df (accessed 1 June 2011)

54. Carrad L. Policy development in mentoring and volunteering. In: Miller A, editor. Mentoring, citizenship and the community. Report of the third annual conference of the London Mentoring Network. London: Learning and Skills Council, 2002.

55. Page BJ, Loots A, Du Toit DF. Perspectives on a South African tutor/mentor program: the Stellenbosch University experience. M \& T 2005: 13: 5-21.

56. Glass N, Walter R. An experience of peer mentoring with student nurses: enhancement of personal and professional growth. J Nurs Educ 2000: 39: 1-6.

57. Treston H. Peer mentoring: Making a difference at James Cook University, Cairns - It's moments like these you need mentors. Innov EducTeach Internat 1999: 36: 236-243. 